\title{
Diet of the southern giant petrel in Patagonia: fishery-related items and natural prey
}

\author{
Sofía Copello ${ }^{1, *}$, Flavio Quintana ${ }^{1,2}$, Fabián Pérez ${ }^{1,3}$ \\ ${ }^{1}$ Centro Nacional Patagónico (CONICET), U9120ACF Puerto Madryn, Argentina \\ ${ }^{2}$ Wildlife Conservation Society, New York, New York 10460, USA \\ ${ }^{3}$ Present address: Ecocentro, Julio Verne 3784, U9120ACF Puerto Madryn, Argentina
}

\begin{abstract}
There is an increasing interest in dietary composition of threatened seabirds as an important key to understanding their feeding ecology, population dynamics and interaction with fisheries. Several seabird species exploit discards from fisheries as their main food. The southern giant petrel Macronectes giganteus is a wide-ranging procellariform. It is considered a near-threatened species under International Union for Conservation of Nature (IUCN) criteria and has been included as a threatened species in the Appendix 2 of the Convention on the Conservation of Migratory Species of Wild Animals. The diet of Patagonian colonies of this species remains unknown, even though understanding the relationship between southern giant petrels and fisheries may be crucial to the conservation of this species in the Southwestern Atlantic. We describe the diet of the southern giant petrel from north Patagonian colonies using chick regurgitations and evaluate its relationships with the fisheries. Carrion occurred in the diets of $90.8 \%$ of birds sampled, while cephalopods occurred in the diets of $65.1 \%$. Crustaceans were present in $43.7 \%$ of samples and fishes in $19.4 \%$. Anthropogenic items were found in $72.7 \%$ of the samples. The presence in the petrel's diet of target and discarded species from fishery vessels, and the high incidence of marine debris, suggests an extensive use of discard over the Patagonian Shelf. The population of southern giant petrels in northern Patagonia has reached higher, stable levels. Such a population trend could be linked, at least partially, to the use of fisheries discards.
\end{abstract}

KEY WORDS: Diet - Southern giant petrel - Macronectes giganteus - Patagonia - Fisheries · Discard use $\cdot$ Anthropogenic items

\section{INTRODUCTION}

There is an increasing interest in studying dietary composition and feeding ecology of threatened seabirds as an important key to understanding the dynamics of their populations and as indicators of environmental health (see review Shealer 2002). Discards and fish waste produced by vessels constitute an abundant and spatio-temporally predictable food source that several seabird species exploit as their main food (see review Furness 2003). Seabird populations may be both negatively and positively affected by fisheries activities. They can benefit from an increase in prey abundance due to fishery waste, reduction in stocks of predatory fishes and increases in abundance of small prey. On the other hand, they could be harmed as a result of incidental mortality, decreases in prey species and increases in scavengers and predator populations (see review Tasker et al. 2000). Increases in many seabird populations may be consequence of the use of fishing waste (Woehler et al. 2002, Yorio et al. 2005) and the surplus food could play a key role in the feeding ecology and population dynamic of seabirds. Therefore, information on the relationship between seabird diet and fisheries is important for the management and conservation of some seabird populations.

The Patagonian Shelf, which extends from northern Argentina southwards to Tierra del Fuego and around the Falkland (Malvinas) Islands, is a highly productive area supporting major squid and fin-fish resources, and a corresponding large and diverse community of top predators (Croxall \& Wood 2002). Economically, 
fishing is the most important activity associated with the Patagonian Shelf. The fishing fleet is made up of 3 main types of vessels: trawlers, jiggers and longliners. Only 3 to 10 longline vessels (less than $1 \%$ of the total national fishing fleet) operate in Argentine waters, in contrast to 109 to 119 trawlers, 105 to 155 jiggers and 60 double-beam trawlers (Bezzi et al. 2000). In addition, about 61 to 82 jiggers operate in international waters along the shelf break at the Southwestern Atlantic Ocean (Waluda et al. 2002).

The southern giant petrel Macronectes giganteus has been seen feeding on fishing discards from trawler operating over the Patagonian Shelf (Yorio \& Caille 1999) and, given the huge expansion of fisheries over the Patagonian Shelf over the last 10 yr (SAGPyA, www.sagpya.mecon.gov.ar), we consider that scavenging on fishery-associated resources may have become an important part of its feeding ecology. M. giganteus is considered a near-threatened species under International Union for Conservation of Nature (IUCN) criteria (www.iucnredlist.org) and has been included as a threatened species in the Appendix 2 of the Convention on the Conservation of Migratory Species of Wild Animals (www.cms.int). Although the global population has showed a decline of some $17.5 \%$ compared to values reported by Hunter (1985), some colonies have increased or remained stable over recent years (Cuthbert \& Sommer 2004, Creuwels et al. 2005, Quintana et al. 2006). In Argentina, $80 \%$ of the population occurs to the north of San Jorge Gulf, where 2300 breeding pairs occur (Quintana et al. 2006). All previous studies on $M$. giganteus diet have been restricted to Sub-Antarctic and Antarctic colonies and have been carried out during 1 or 2 seasons (Mougin 1968, Conroy 1972, Johnstone 1977, Hunter 1983, Hunter \& Brooke 1992). The diet of this species remains unknown for the Patagonian colonies even though understanding the relationship between southern giant petrels and fisheries may be crucial to the conservation of this species in the Southwestern Atlantic ecosystem. Here we describe the diet of the southern giant petrel from north Patagonian colonies during the chick-rearing period in 4 consecutive breeding seasons. We evaluate the potential relationships between the diet and fisheries activities at the Patagonian Shelf.

\section{MATERIALS AND METHODS}

Study site and sampling method. The study was conducted at Isla Arce $\left(45^{\circ} 00^{\prime} \mathrm{S}, 65^{\circ} 50^{\prime} \mathrm{W}\right)$ and Gran Robredo $\left(45^{\circ} 08^{\prime} \mathrm{S}, 66^{\circ} 03^{\prime} \mathrm{W}\right)$ on the Patagonian Shelf, Argentina, in the Southwestern Atlantic Ocean (Fig. 1). A total of 280 food samples were taken from randomly selected chicks between January and March over 4 consecutives breeding seasons (2001 to 2004, Table 1). We sampled chicks from separate areas of the colony to avoid handling the same chicks more than once. Due to logistic constraints making it impossible to stay in the study area for a long time and because the southern giant petrel is extremely sensitive to human disturbance in breeding colonies, food samples were not necessarily taken after a returning parent had completed feeding the chick. Even though pseudoreplication (i.e. among preys, among preys within the same regurgitate) is inherent in this type of sampling method, analysis of spontaneous chick regurgitations is an appropriate methodology to determine the diet in the Macronectes giganteus and other Procellaridae because it does not lead to an underestimation of the importance of soft prey items (Duffy \& Jackson 1986). Chicks regurgitate easily during handling and, unlike with manipulation of adults, this does not increase the risk of desertion (Hunter 1983).

To evaluate temporal variation in diet, and given that hard prey items could stay during a long time in the procellariform chicks stomach (Warham 1996), during the 2002 to 2004 breeding seasons, we took sub-samples from the same group of chicks $(\sim 10$ birds per season) when they were aged 30 to 45 and 60 to $75 \mathrm{~d}$. Samples were obtained by up-ending chicks over a plastic bucket and massaging the stomach and throat. The sample was strained, the liquid removed and all samples preserved in $70 \%$ alcohol for later analysis.

Dietary analysis. Once in the laboratory, samples were thawed and drained, the remaining solid components were removed, and the presence and absence of different items was determined. Some prey items were identified using bones, gladius and squid or fish eye lenses. Prey species were identified to the lowest taxonomic level using lower beaks (cephalopods), feathers (penguins and flying birds), bones and otoliths (fish), exoskeletons (crustaceans) and hair (marine mammals) using guides, keys (Boschi et al. 1992, Gosztonyi \& Kuba 1996, Pineda et al. 1996, Ivanovic \& Brunetti 1997) and reference collections. The lower rostral and otolith lengths were measured using a vernier caliper to an accuracy of $0.01 \mathrm{~mm}$. Allometric equations were used to relate the lower rostral and otolith lengths to the original wet body mass, mantle and total lengths (Pineda et al. 1996, Ivanovic \& Brunetti 1997, Koen Alonso et al. 1998, 2000). The number of squid per sample was determined by counting the number of lower and upper beaks; when the number differed, the larger of the two was used. The anthropogenic items were categorized as 'plastic,' 'nylon lines,' 'vegetables,' 'aluminum foil,' 'paper,' 'wood,' 'rope' and 'other' (including rubber foam, wire and Styrofoam). Each item was weighed using an electronic balance to an accuracy of $0.01 \mathrm{~g}$. 

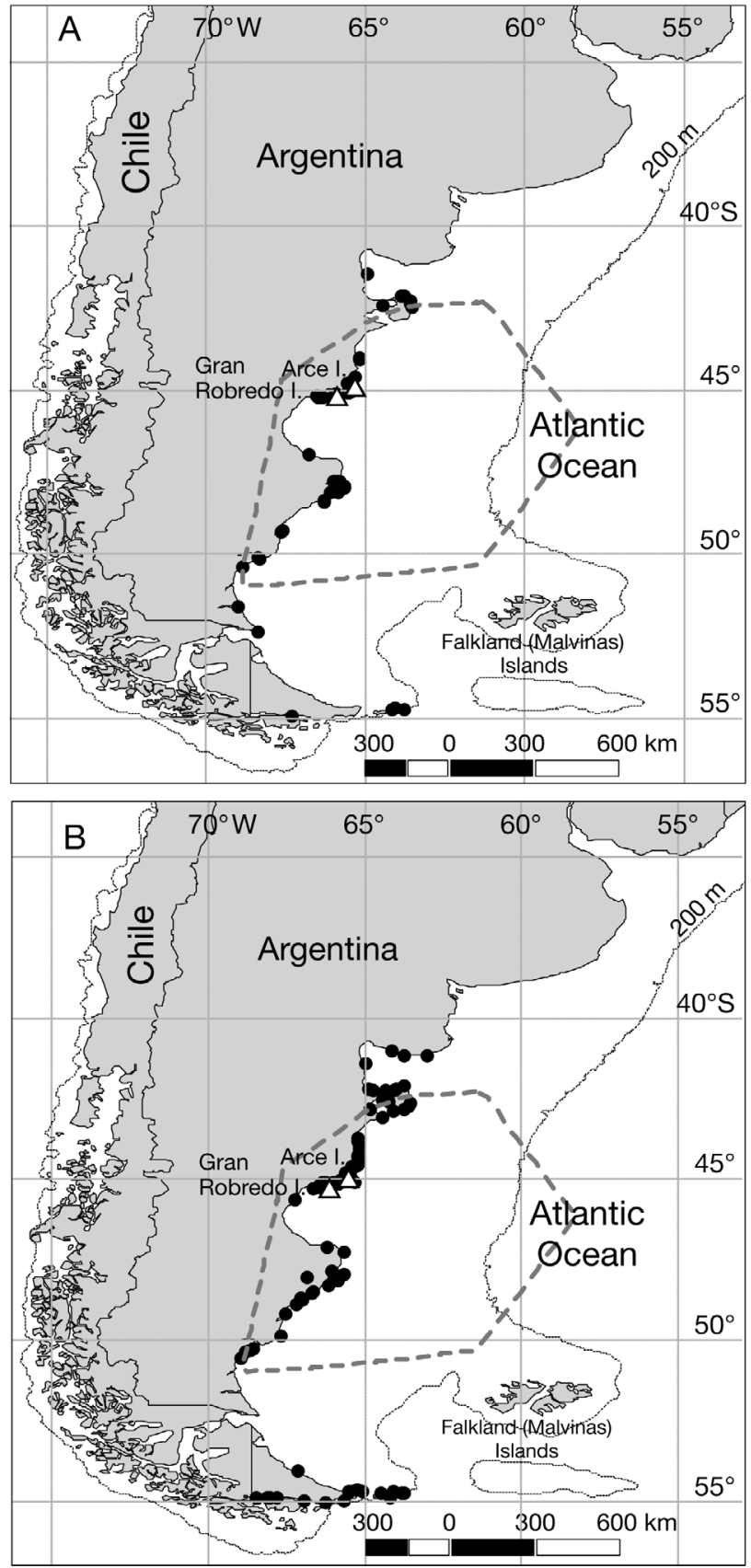

Fig. 1. Study area, showing the locations of the studied colonies of Macronectes giganteus $(\Delta)$ as well as the distribution of (A) penguin and (B) sea lion colonies along the Patagonian coast of Argentina (@). Source: Reyes et al. (1999), Dans et al. (2004), Schiavini et al. (2005). Dashed gray line shows the foraging range (minimum convex polygon, $\mathrm{MCP}$ ) of adults/breeders from both colonies

Data analysis. For each prey item we calculated the frequency of occurrence $(\% \mathrm{FO}=100 \times$ number of samples in which a particular item appeared/total number of samples) and for cephalopods we calculated the numerical frequency (beaks number/total number of beaks). Independence among observations is a basic assumption for the statistical test. This condition is not guaranteed for items in a food sample, however we assume that each item can be considered as independent. Other indices as percentages by fresh mass or numerical abundance were not used, given the high state of digestion of the food samples. One-way ANOVA, Kruskal-Wallis test and non-balanced Tukey's multiple comparison were used to examine inter-annual variation in mantle length, weight and number of cephalopods per sample. Similarities in dietary composition among seasons, periods and colonies were studied with multivariate techniques included in the PRIMER suite of programs. We generated a Bray-Curtis similarity matrix to assess similarities in prey-group composition between samples using non-parametric multi-dimensional scaling (MDS). A stress coefficient was calculated for each axis, representing the extent to which the relationship between the samples was adequately represented in 2 dimensions. Stress values lower than 0.1 indicate that the axis is a good representation of the data. Stress levels between 0.1 and 0.2 also point to a good representation in the space, although too much reliance should not be placed on the detail of the plot, and values higher than 0.3 indicate the results should be treated with caution in interpreting any apparent pattern in the samples, intimating that the inclusion of more dimensions in the analysis would be beneficial. We tested for significant differences in diet composition among seasons, colonies and periods, using a multivariate analysis of similarities (ANOSIM) (Clarke \& Warwick 2001), which is analogous to a univariate ANOVA. This procedure uses the Bray-Curtis similarity matrix to compute a test statistic $\mathrm{R}$. $\mathrm{R}$ is standardized so that a value of 1 means that all the samples within a group is more similar than any sample from the other group. $\mathrm{R}$ is approximately zero if there are no differences between groups. A randomization process is used to find the probability of gaining particular values of R by chance (Clarke \& Warwick 2001).

\section{RESULTS}

\section{Overall composition}

The analysis of chick regurgitations during the studied period showed a diet comprised of carrion and live prey. At least 23 items were identified, including anthropogenic items (Table 1). Carrion (remains of penguins, sea lions and flying birds) was the most common prey group (occurring in $90.8 \%$ of samples), followed by cephalopods (occurring in $65.1 \%$ of samples). Crustaceans were present in $43.7 \%$ of samples and fishes in $19.4 \%$. Anthropogenic items were found in $72.7 \%$ of 
Table 1. Macronectes giganteus. Percentage of occurrence (\%) of prey items in southern giant petrel diet at Isla Arce and Gran Robredo colonies, Patagonia, Argentina, during 2001 to 2004 breeding seasons. Total number of food samples in parentheses

\begin{tabular}{|c|c|c|c|c|c|}
\hline Taxonomic & $\begin{array}{c}2001 \\
(72)\end{array}$ & $\begin{array}{c}2002 \\
(60)\end{array}$ & $\begin{array}{c}2003 \\
(50)\end{array}$ & $\begin{array}{c}2004 \\
(98)\end{array}$ & $\begin{array}{l}\text { Total } \\
(280)\end{array}$ \\
\hline Carrion & 100.0 & 80.6 & 96.1 & 87.9 & 90.8 \\
\hline Penguins & 95.8 & 74.2 & 96.1 & 85.9 & 87.7 \\
\hline Flying birds & 2.8 & 0 & 2.0 & 5.1 & 3.3 \\
\hline Sea lions & 47.2 & 48.4 & 47.1 & 31.3 & 41.9 \\
\hline Cephalopods & 69.4 & 56.5 & 64.7 & 67.7 & 65.1 \\
\hline Illex argentinus & 100.0 & 91.7 & 94.7 & 87.0 & 93.2 \\
\hline Loligo & 0 & 0 & 0 & 34.8 & 10.8 \\
\hline Octopuses & 4.3 & 25.0 & 8.3 & 4.2 & 7.5 \\
\hline Crustaceans & 38.9 & 27.4 & 68.6 & 44.4 & 43.7 \\
\hline Pleoticus muelleri & 85.7 & 16.7 & 59.5 & 14.3 & 42.2 \\
\hline Peisos petrunkevitchi & 0 & 0 & 40.5 & 42.9 & 32.6 \\
\hline Stomatopoda & 0 & 38.9 & 2.7 & 0 & 6.1 \\
\hline Munida spp. & 0 & 22.2 & 0 & 0 & 3.0 \\
\hline Isopods & 0 & 0 & 0 & 8.2 & 3.0 \\
\hline Brachyura & 3.6 & 0 & 0 & 0 & 0.8 \\
\hline Non-identified & 10.7 & 22.2 & 8.1 & 20.4 & 18.2 \\
\hline Fishes & 22.2 & 17.7 & 9.8 & 23.2 & 19.4 \\
\hline Macruronus magellanicus & 16.7 & 0 & 0 & 0 & 16.7 \\
\hline Merluccius hubbsi & 0 & 16.7 & 0 & 33.3 & 50.0 \\
\hline Raneya brasiliensis & 0 & 16.7 & 16.7 & 0 & 33.3 \\
\hline Non-identified & 96.4 & 90.0 & 95.2 & 92.5 & 93.6 \\
\hline Anthropogenic items & 72.2 & 64.5 & 78.4 & 73.7 & 72.7 \\
\hline Plastics & 66.0 & 59.2 & 64.4 & 79.5 & 69.1 \\
\hline Vegetables & 34.0 & 24.5 & 37.8 & 41.0 & 35.2 \\
\hline Plastic lines & 35.8 & 22.4 & 22.2 & 2.4 & 18.3 \\
\hline Rope & 1.9 & 12.2 & 31.1 & 4.8 & 10.9 \\
\hline Paper & 9.4 & 10.2 & 4.4 & 13.3 & 10.0 \\
\hline Wood & 13.2 & 12.2 & 8.9 & 1.2 & 7.8 \\
\hline Aluminium & 9.4 & 0 & 0 & 0 & 2.2 \\
\hline Others & 15.1 & 4.1 & 6.7 & 4.8 & 9.6 \\
\hline
\end{tabular}

at low percentages of occurrence $(<5 \%)$ (Table 1). Carrion composition was similar among years (ANOSIM, R $=-0.001$, $\mathrm{p}>0.1$ ).

\section{Cephalopods}

A total of 276 mandibles of cephalopods were collected (137 lowers and 139 uppers) from 117 samples over the $4 \mathrm{yr}$ period. The mean number of cephalopods per sample was similar among years $(2.2 \pm 1.9 \mathrm{SD}$, range $=1$ to $10, \mathrm{H}=8.6, \mathrm{p}>0.05)$. The cephalopod composition was similar among years (ANOSIM, R =0.013, p > 0.1). Over all seasons, Argentine shortfin squid Illex argentinus was the most frequently encountered squid (93.2\% of all samples with lower mandibles, Table 1) and the most important by number $(89.8 \%)$. The average mantle length of this prey item was $194.5 \pm 26.3 \mathrm{~mm}$ (range $=120.0$ to 259.8, mode $=190$, Fig. 2) and mean weight was $179.4 \pm$ $70.8 \mathrm{~g}$ (range $=37.4$ to 401.9 ), both values estimated using lower mandibles. However, differences among years were apparent $\left(F_{\text {mantle length }(3,119)}=4.24\right.$ and $\left.F_{\text {weight: }(3,119)}=4.66, \mathrm{p}<0.05\right)$. Estimated sizes and weights of Argentine shortfin squid were higher in 2001 than 2003 (205.3 $\mathrm{mm}$ vs. $185.3 \mathrm{~mm}$ and the samples (Table 1). Dietary composition (by prey group) showed a high level of overlap between years and colonies (MDS: stress < 0.17). MDS in 2 dimensions indicated a clear overlap between samples from different years and colonies. This pattern was supported by ANOSIM results with low $\mathrm{R}$ values, which indicates a high overlap $\left(\mathrm{R}_{\text {year }}=0.008, \mathrm{p}>0.1 ; \mathrm{R}_{\text {colony }}=0.017, \mathrm{p}>\right.$ 0.1). Diet composition showed a clear level of overlap between chicks of 30 to 45 and 60 to $75 \mathrm{~d}$ old (MDS: stress $<0.17)$. The ANOSIM results supported the same pattern $(\mathrm{R}=0.045, \mathrm{p}>0.05)$.

\section{Dietary composition by prey group}

\section{Carrion}

Penguins were the prey with highest percentage of occurrence over the 4 seasons $(>74 \%)$, while sea lions were present in less than $50 \%$ of the samples. Flying birds occurred in all seasons except 2002, but
$209.0 \mathrm{~g}$ vs. $151.1 \mathrm{~g}$ for mantle length and weight, respectively) (Tukey's test, $\mathrm{MS}_{\text {mantle length }}=639.3 \mathrm{df}=$ $119, \mathrm{p}<0.05$ and $\mathrm{MS}_{\text {weight }}=4605.5, \mathrm{df}=119, \mathrm{p}<0.05$ ). The frequency distribution of mantle length showed similar size range over the 4 seasons (from 130 to 260 mm, Fig. 2). In 2004, 8 samples (FO 10.8\%, Table 1) contained longfin beaks (Loligo sp.) and the importance by number was $9.5 \%$. The average estimated size of Loligo was $138.2 \pm 62.8 \mathrm{~mm}$ (range $=90.1$ to 324.1 ) and the weight was $73.7 \pm 123.6 \mathrm{~g}$. The level of species for Loligo sp. was identified in a single sample and represented 2 lower beaks of Patagonian longfin squid L. gahi. Octopuses occurred in all breeding seasons at a percentage of occurrence of $7.5 \%$ and a numerical percentage of occurrence of $3.6 \%$.

\section{Crustaceans}

Patagonian red shrimp Pleoticus muelleri and white shrimp Peisos petrunkevitchi were the crustaceans 


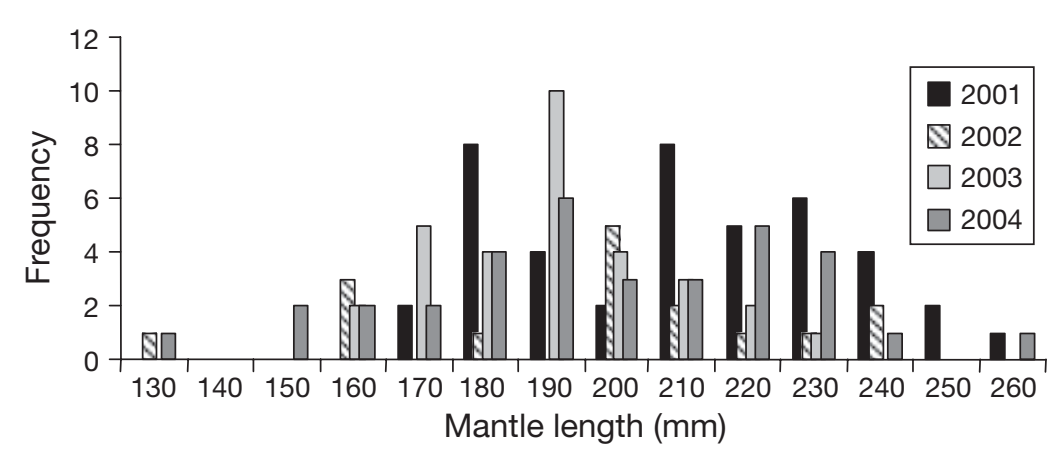

Fig. 2. Illex argentinus. Frequency distribution of mantle length of Argentine shortfin squid consumed by Macronectes giganteus in Patagonia during 2001 to 2004 breeding seasons

\section{DISCUSSION}

Our findings concerning southern giant petrel diet over the Patagonian Shelf emphasize the role of these birds as scavengers and predators, as has been previously documented during studies in Antarctic and Sub-Antarctic colonies (Hunter 1983, Hunter \& Brooke 1992). For adult breeders from the northern colonies of Patagonia (Isla Arce and Gran Robredo), penguins were the item with highest percentage of occurrence in the diet (FO 87.7\%), while sea lions were consumed less frequently $(41.9 \%)$.

with highest percentage of occurrence in the diet of the southern giant petrel during the study period $(42.2 \%$ and $32.6 \%$, respectively). The stomatopods, Munida spp., Brachyura and isopods had lower percentage of occurrence $(<10 \%)$. We found significant differences in crustacean composition among years (ANOSIM, $\mathrm{R}=0.228, \mathrm{p}<0.01$ ). Pairwise comparisons showed significant differences among all years $(\mathrm{R}>$ 0.065, p < 0.05).

\section{Fishes}

Only $6(11 \%)$ of 54 samples with fishes had otoliths or bones. One sample contained Patagonian grenadier Macruronus magellanicus, 3 Argentine hake Merluccius hubbsi (130.4 mm, $13.4 \mathrm{~g}$ ) and 2 Raneya Raneya brasiliensis $(210.3 \pm 10 \mathrm{~mm}, 48.3 \pm 0.7 \mathrm{~g})$ (Table 1$)$.

\section{Anthropogenic items}

Plastics were the marine debris with by far the highest percentage of occurrence $(69.1 \%)$ in southern giant petrel food samples over the 4 seasons, followed by vegetables $(35.2 \%)$ and nylon lines (18.3\%). Other items, such as aluminum foil, wood and paper, had a lower percentage of occurrence $(<15 \%)$ (Table 1$)$. Although there were significant differences in marine debris composition among years, the overlap was high (small R value, ANOSIM, R =0.083, p < 0.01). Pairwise comparisons showed differences of all years compared with $2004(\mathrm{R}=0.108,0.111$ and 0.134 for 2001, 2002 and 2003, respectively, $\mathrm{p}<0.01$ ).

A total of $238.5 \mathrm{~g}$ of debris was extracted from chicks' stomachs, composed of $180.6 \mathrm{~g}$ of plastics, $105.5 \mathrm{~g}$ of vegetables, $23.0 \mathrm{~g}$ of paper and $17.3 \mathrm{~g}$ of wood. The lightest items were nylon lines and other items $(<5 \mathrm{~g})$. The mean weight of litter per sample was $1.9 \pm 3.8 \mathrm{~g}$.
Although southern giant petrels have been seen preying on live Magellanic penguins and other seabird species (Punta \& Herrera 1995, Descamps et al. 2005, F. Quintana pers. comm.), a considerable part of this food source could come from dead adults and/or chicks of both species. Predatory behavior of the southern giant petrel is not frequent and probably displayed by a few specialist birds with low impact on specific penguin or sea lion populations (Descamps et al. 2005). Penguin and sea lion carrion make up an abundant and predictable food source along the Patagonian coast. About 950000 penguin breeding pairs (Schiavini et al. 2005) and 65000 South American sea lions (Reyes et al. 1999, Dans et al. 2004) breed along the coast. The highest densities of both carrion/prey species are concentrated at the northern end of the San Jorge Gulf in coastal areas in the vicinities of the southern giant petrel colonies (Copello 2007) (Fig. 1). In fact, both northern colonies are located close to both carrion/ prey species' colonies (Reyes et al. 1999, Schiavini et al. 2005) and the biggest penguin colony in Patagonia, Punta Tombo ( 175000 nests), is less than $100 \mathrm{~km}$ from the southern giant petrel colonies. During breeding season, adults showed a spatial association with areas of high concentration of penguins and sea lions (Fig. 1). In addition, there is a remarkable temporal overlap between the breeding season of scavenger/predator and prey species. While the chick-rearing period of the southern giant petrel goes from early January to late April, and Magellanic penguins hatch during November, petrel chicks remain in the colonies up to early February and moulting penguins (adults and juveniles) congregate at the coast up to late March (Schiavini et al. 2005). Sea lion pups born between December and February and yearlings leave their breeding sites in late April (Campagna 1985). In coastal Patagonia, Magellanic penguins and southern sea lions show different population trends; while sea lions have shown a population recovery over the last few decades (Reyes et al. 1999, Dans et al. 2004), penguin numbers have both increased and 
declined, depending on the colony (Schiavini et al. 2005). Changes in the carrion/prey populations could play a key role in the population dynamics of southern giant petrels in Patagonia. Population declines and increases in southern giant petrel colonies (mainly at Sub-Antarctic islands) have been attributed to fluctuations in breeding populations of sea lions, elephant seals and penguins in neighboring areas (Woehler 1991, González-Solís et al. 2000, Briggs \& Humpidge unpubl. data).

Cephalopods were also an important prey (FO $65.1 \%$ ) in the diet of the giant petrels, with the Argentine shortfin squid Illex argentinus being the most important in terms of percentage of occurrence and number over the 4 studied seasons. In the Patagonian Shelf area, I. argentinus is an important prey in the diet of resident top predators as well as visiting seabirds (Eder \& Lewis 2005). The squid, as is the case in most of the ommastrephid species, are separated into different breeding stocks (Brunetti et al. 1998), which can be differentiated by considering size, total length at maturity, distribution and spawning time (Brunetti et al. 1998). The size consumed by the southern giant petrels during the breeding period (Fig. 2) was similar to that found in the summer spawning stock (SSS) and the South-Patagonic stock (SPS) during January and February. The highest abundances of these stocks were located within the foraging range of giant petrels from Isla Arce and Gran Robredo (Quintana \& Dell' Arciprete 2002). We note here that small squids could be underestimated, since small beaks can pass through the digestive system more easily (Duffy \& Jackson 1986).

The Argentine shortfin squid Illex argentinus occurs at the sea bottom during the day (Moiseev 1991) and does not float when dead (Lipinski \& Jackson 1989), so it can only be captured alive by surface feeders at night, when it swims close to the surface. However, it is also highly probable that this species could also be obtained from discards of trawlers and jiggers that catch squid and other commercial species. In fact, recent data showed that the activity of those fisheries in the Patagonian Shelf showed a clear spatio-temporal overlap with the foraging areas of southern giant petrels tracked by satellite from Isla Arce and Gran Robredo (see Fig. 3) (Copello \& Quintana unpubl. data). We note that giant petrels have been widely reported as one of the main 'followers' of trawlers vessels in the Patagonian Shelf (Yorio \& Caille 1999). Studies in waters around Falklands (Malvinas) Islands showed that the black-browed albatross Diomedea melanophris obtained between 4 to $15 \%$ of its total food requirement from the squid and finfish trawlers (Thompson 1992, Thompson \& Riddy 1995). The night activity of the huge jigger fleet fishing at the shelf
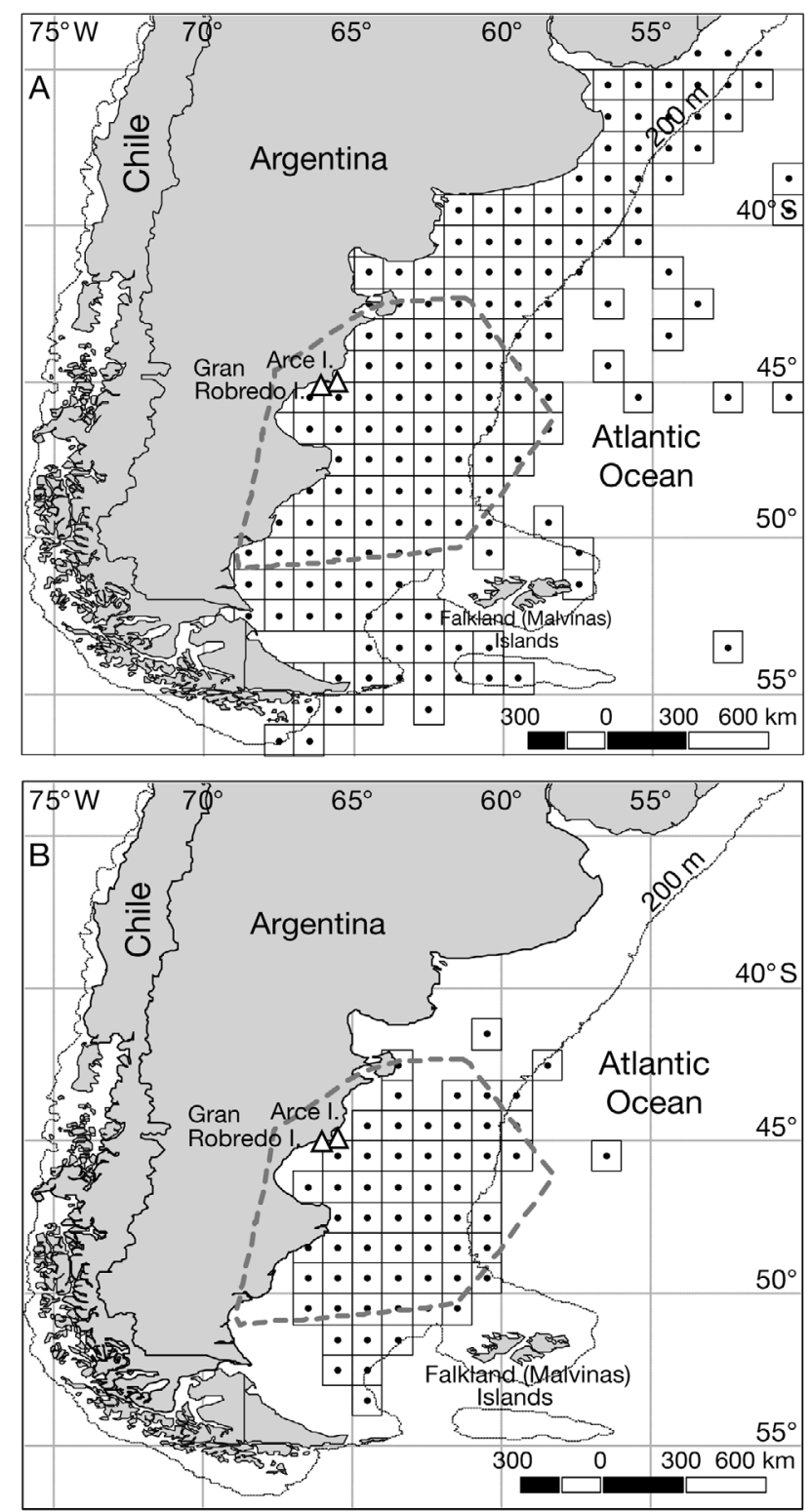

Fig. 3. Spatial distribution $\left(1 \times 1^{\circ}\right)$ of $(A)$ trawlers and (B) jiggers over the Patagonian shelf during the summers of 1999, 2000, 2002 and 2004. Data were obtained from National Fishing reports provided by the Instituto Nacional de Investigación y Desarrollo Pesquero (INIDEP, National Institute of Fisheries Research and Development). Dashed gray line shows the foraging range (minimum convex polygon, $\mathrm{MCP}$ ) of Macronectes giganteus adults/breeders from both colonies. $(\Delta)$ Locations of the studied colonies

break by means of powerful lights (Rodhouse et al. 2001) could also facilitate the capture of squid by the southern giant petrels and other surface feeders. As consequence of the use of such lights, squids migrate from the sea-bottom to the surface, thus becoming more accessible to the giant petrels. In fact, giant petrels have been seen following jiggers operating in 
the shelf break near Falklands (Malvinas) Islands and the San Matías Gulf in coastal waters of Argentina (M. Savigny \& O. Yates pers. comm.).

The occurrence of crustaceans (Pleoticus muelleri and Peisos petrunkevitchi) and fishes (Macruronus magellanicus, Merluccius hubbsi and Raneya brasiliensis) in the diet of the southern giant petrel lends support to the importance of discard from trawler vessels for this species. Normally, these demersal and benthic species would not be available to petrels (Boschi et al. 1992, Cousseau \& Perrotta 2003). In fact, all the crustacean and fish species mentioned are captured by the major trawler fleets operating on the Patagonian Shelf - the double-beam trawlers, which target Patagonian red shrimp, as well as the trawlers targeting Argentine hake (Pettovello 1999, Irusta et al. 2001). However, some of these crustaceans and fishes could also results from a secondary consumption on carrion, in association with sub-surface foragers that forced prey to the surface or scavenging dead floating prey (see review Shealer 2002).

As in a previous study conducted over a single season (Copello \& Quintana 2003), the incidence of anthropogenic items was high during all seasons $(>64.5 \%)$, with plastics showing the highest percentage of occurrence $(>59.2 \%)$. The literature on marine debris leaves no doubt that plastics make up most of the marine litter worldwide, ranging between 60 and $80 \%$ of the total waste disposal at sea (see review Derraik 2002). The occurrence of marine debris in diet has previously been reported for several procellarid species (see review Burger \& Gochfeld 2002), but not in the southern giant petrel. Only Nel \& Nel (1999) describe the presence of marine debris associated with southern giant petrel nests. The ingestion of plastics has been reported to cause deleterious effects in seabirds, including complicating regurgitation and clogged gizzards. In addition, the concentration of toxic compounds (e.g. PCBs) can reduce breeding success, increase risk of disease, alter hormone levels and interfere with the formation of fat deposits (see review Burger \& Gochfeld 2002). Although we were not able to identify the sources of the marine debris recorded in the diet samples of southern giant petrels in this study, there is evidence to suggest that they are derived from fishing activities. As we mentioned above, during the breeding season, southern giant petrels from Arce and Gran Robredo Islands use a huge area of the Patagonian Shelf to feed and birds showed a clear spatio-temporal overlap with fishing activities (Copello 2007). Giant petrels have been seen feeding not only on discards, but also on garbage thrown overboard (E. Bogazzi \& F. Firstater pers. comm.). The marine debris could come mainly from trawlers and jiggers given that, as mentioned above, crustaceans, fishes and squid found in food samples were caught and/ or discarded by those fisheries (Brunetti et al. 1998, Pettovello 1999, Irusta et al. 2001).

This study provides the first record of food sources of the southern giant petrel from northern colonies of Patagonia, Argentina. The presence in the diet of target and discarded species from fishery vessels, and the high incidence of marine debris, suggests an extensive use of discard over the Patagonian Shelf. The population of the southern giant petrel in north Patagonia, Argentina, has reached higher, stable levels (Quintana et al. 2006). Such a population trend could be linked, at least partially, to the use of fisheries discards, though the negative impact of fisheries on this species via incidental mortality has been noted. However, the rates of this appear too low to significantly affect the petrel's population status (Favero et al. 2003). Moreover, the high carrion abundance and the proximity and productivity of coastal and pelagic feeding areas could also be important factors related to southern giant petrel population dynamics in northern colonies of Patagonia.

Acknowledgements. This study was funded by the Wildlife Conservation Society, Agencia Nacional de Promoción Científica y Tecnológica and Centro Nacional Patagónico (CONICET). The Instituto de Investigación y Desarollo Pesquero (INIDEP) provided us with spatial data on fisheries. We are grateful to G. Casas, M. Re and N. García for discussions on prey identification. We are thankful to G. Morales, W. 'Tito' Svagelj, A. Gatto, M. Uhart, I. Escapa, D. González-Zevallos, A. Sapoznikow, J. 'Chochi' Owen, R. 'Bebo' Vera, N. Ortiz and M. A. 'Hormiga' Díaz for field support. We thank D. Galván and A. Sapoznikow for statistical advice and 2 anonymous reviewers for critical comments that improved the manuscript.

\section{LITERATURE CITED}

Bezzi S, Akselman R, Boschi E (2000) Síntesis del estado de las pesquerías marítimas argentinas y de la cuenca del plata. Años 1997-1998, con actualización del 1999, Vol. INIDEP, SAGPyA, Mar del Plata

Boschi E, Fischbach CE, Iorio MI (1992) Catálogo ilustrado de los crustáceos estomatópodos y decápodos marinos de Argentina. Frente Maritimo 10:7-94

Brunetti NE, Ivanovic ML, Rossi GR, Elena B, Pineda S (1998) Fishery biology and life history of Illex argentinus. In: Okuytani T (ed) International Symposium on large pelagic squids. Japan Marine Fishery Resources Research Center, p 21-231

Burger J, Gochfeld M (2002) Effects of chemical and pollution on seabirds. In: Schreiber EA, Burger J (eds) Biology of marine birds. CRC Press, Boca Raton, FL, p 486-514

Campagna C (1985) The breeding cycle of the southern sea lion, Otaria byronia. Mar Mamm Sci 1:210-218

Clarke KR, Warwick RM (2001) Change in marine communities: an approach to statistical analysis and interpretation, vol. PRIMER-E Ltd, Plymouth 
Conroy JWH (1972) Ecological aspects of the biology of the giant petrel Macronectes giganteus (Gmelin) in the maritime Antarctic. Sci Rep Br Antarct Surv 75:1-74

Copello S (2007) Ecología y conservación del petrel gigante del sur (Macronectes giganteus) en Patagonia, Argentina. Tesis Doctoral, Universidad Nacional del Comahue

$>$ Copello S, Quintana F (2003) Marine debris ingestion by Southern Giant Petrels and its potential relationships with fisheries in the Southern Atlantic Ocean. Mar Pollut Bull 46:1513-1515

Cousseau MB, Perrotta RG (2003) Peces marinos de Argentina: Biología, distribución, pesca. INIDEP, Mar del Plata

Creuwels JCS, Stark JS, Woehler EJ, Van Franeker JA, Ribic CA (2005) Monitoring of a Southern Giant Petrel Macronectes giganteus population on the Frazier Islands, Wilkes Land, Antarctica. Polar Biol 28:483-493

Croxall JP, Wood AG (2002) The Importance of the Patagonian Shelf for top predator species breeding at South Georgia. Aquat Conserv 12:101-118

Cuthbert R, Sommer ES (2004) Population size and trends of four globally threatened seabirds at Gough Island, South Atlantic Ocean. Mar Ornithol 32:97-103

Dans SL, Crespo E, Pedraza SN, Koen Alonso M (2004) Recovery of the South American sea lion (Otaria flavescens) population in northern Patagonia. Can J Fish Aquat Sci 61:1681-1690

Derraik JGB (2002) The pollution of the marine enviroment by plastic debris: a review. Mar Pollut Bull 44:842-852

> Descamps S, Gauthier-Clerc M, Le Bohec C, Gendner JP, Le Maho Y (2005) Impact of predation on king penguin Aptenodytes patagonicus in Crozet Archipelago. Polar Biol 28:303-310

Duffy DC, Jackson S (1986) Diet studies of seabirds: a review of methods. Colonial Waterbirds 9:1-17

Eder EB, Lewis MN (2005) Proximate composition and energetic value of demersal and pelagic prey species from the SW Atlantic Ocean. Mar Ecol Prog Ser 291:43-52

Favero M, Khatchikian CE, Arias A, Silva-Rodriguez MP, Mariano-Jelicich R (2003) Estimates of seabird by-catch along the Patagonian Shelf by Argentine longline fishing vessels, 1999-2001. Bird Conserv Int 13:273-281

Furness RW (2003) Impacts of fisheries on seabird communities. Sci Mar 67:33-45

González-Solís J, Croxall JP, Wood AG (2000) Foraging partitioning between giant petrels Macronectes spp. and its relationship with breeding population changes at Bird Island, South Georgia. Mar Ecol Prog Ser 204:279288

Gosztonyi AE, Kuba L (1996) Atlas de los huesos craneales y de la cintura escapular de peces costeros patagónicos. Report No. 4, GEF/ PNUD/WCS/Fundación Patagonia Natural, Puerto Madryn

Hunter S (1983) The food and feeding ecology of the giant petrels Macronectes halli and M. giganteus at South Georgia. J Zool 200:521-538

Hunter S (1985) The role of giant petrels in the Southern Ocean ecosystem. In: Siegfried WR, Condy PR, Laws RM (eds) Antarctic nutrient cycles and food webs. Springer, Berlin, p 534-542

Hunter S, Brooke MDL (1992) The diet of giant petrels Macronectes spp. at Marion Island, Southern Indian Ocean. Colon Waterbirds 15:56-65

Irusta CG, Castrucci R, Blanco G (2001) Análisis espacio-temporal de los rendimientos de merluza (Merluccius hubbsi) y de otros organismos de su fauna acompañante. Report No. 59, INIDEP, Mar del Plata
Ivanovic ML, Brunetti NE (1997) Description of Illex argentinus beaks and rostral length relationships with size and weight of squids. Rev Investig Desarro Pesq 11:135-144

Johnstone GW (1977) Comparative feeding ecology of giant petrels Macronectes giganteus (Gmelin) and M. halli (Mathews). In: Llano GA (ed) Adaptations within Antarctic ecosystems. Smithsonian Institution, Washington, DC, p 647-688

Koen Alonso M, Crespo EA, García NA, Pedraza SN, Coscarella MA (1998) Diet of dusky dolphins, Lagenorhynchus obscurus, in waters off Patagonia, Argentina. Fish Bull 96:366-374

Koen Alonso M, Crespo EA, Pedraza SN, García NA, Coscarella MA (2000) Food habits of the South American sea lion, Otaria flavescens, off Patagonia, Argentina. Fish Bull 98:250-263

Lipinski MR, Jackson S (1989) Surface-feeding on cephalopods by procellariiform seabirds in the southern Benguela region. S Afr J Zool 218:549-563

Moiseev SI (1991) Observation of the vertical distribution and behavior of nektonic squids using menned submersibles. Bull Mar Sci 49:446-456

Mougin JL (1968) Etude écologique de quatre espéces de pétrels Antarctiques. Oiseau 38:1-52

Nel DC, Nel JL (1999) Marine debris and fishing gear associated with seabirds at sub-antartic Marion Island, 1996/97 and 1997/98: in relation to longline fishing activity. CCAMLR Science 6:85-96

> Pettovello AD (1999) By-catch in the Patagonian red shrimp (Pleoticus muelleri) fishery. Mar Freshw Res 50:123-127

Pineda SE, Aubone A, Brunetti NE (1996) Identificación y morfometría comparada de las mandíbulas de Loligo gahi y Loligo sanpaulensis (Cephalopoda, Lologinidae) del Atlántico Sudoccidental. Rev Investig Desarro Pesq 10: 85-99

Punta G, Herrera G (1995) Predation by Southern Giant Petrel Macronectes giganteus on adult Imperial Cormorants Phalacrocorax atriceps. Mar Ornithol 23:166-167

Quintana F, Dell' Arciprete P (2002) Foraging grounds of southern giant petrels (Macronectes giganteus) on the Patagonian shelf. Polar Biol 25:159-161

Quintana F, Punta G, Copello S, Yorio P (2006) Population status and trends of Southern Giant Petrels (Macronectes giganteus) breeding in North Patagonia, Argentina. Polar Biol 30:53-59

Reyes LM, Crespo E, Szapkievich V (1999) Distribution and population size of the Southern Sea Lion (Otaria flavescens) in central and southern Chubut, Patagonia, Argentina. Mar Mamm Sci 15:478-493

Rodhouse PG, Elvidge CD, Trathan PN (2001) Remote sensing of the global light-fishing fleet: an analysis of interactions with oceanography, other fisheries and predators. Adv Mar Biol 39:261-303

Schiavini A, Yorio P, Gandini P, Raya Rey A, Boersma D (2005) Los pingüinos de las costas argentinas: estado poblacional y conservación. El Hornero 20:5-23

Shealer DA (2002) Foraging behavior and food of seabirds. In: Schreiber AE, Burger J (eds) Biology of marine birds. CRC Press, Boca Raton, FL, p 137-177

Tasker ML, Camphuysen C, Cooper J, Garthe S, Montevecchi WA, Blaber SJM (2000) The impacts of fishing on marine birds. ICES J Mar Sci 57:531-547

Thompson KR (1992) Quantitative analysis of the use of discards from squid trawlers by Black-browed Albatrosses Diomedea melanophris in the vicinity of the Falkland Islands. Ibis 134:11-21

Thompson KR, Riddy MD (1995) Utilization of offal and discards from 'finfish' trawlers around the Falkland Islands 
by Black-browed Albatross Diomedea melanophris. Ibis 137:198-206

Waluda CM, Trathan PN, Elvidge CD, Hobson VR, Rodhouse PG (2002) Throwing light on straddling stocks of Illex argentinus: assessing fishing intensity with satellite imagery. Can J Fish Aquat Sci 59:592-596

Warham J (1996) The behaviour, population biology and physiology of the petrels. Harcourt Brace \& Company, San Diego, CA

Woehler EJ (1991) Status and conservation of the seabirds of Heard Island and the McDonald Island. In: Croxall JP (ed) Seabird status and conservation: a supplement. Birdlife

Editorial responsibility: Brendan Godley, University of Exeter, Cornwall Campus, UK
International, Cambridge, p 263-275

Woehler EJ, Auman HJ, Riddle MJ (2002) Long-term population increse of black-browed albatrosses Thalassarche melanophrys at Heard Island, 1947/1948-2000/2001. Polar Biol 25:921-927

Yorio P, Caille G (1999) Seabird interactions with coastal fisheries in northern Patagonia: use of discards and incidental captures in nets. Waterbirds 22:201-216

Yorio P, Bertellotti M, García Borboroglu P (2005) Estado poblacional y de conservación de gaviotas que se reproducen en el litoral marítimo argentino. El Hornero 20: $53-74$

Submitted: October 24, 2007; Accepted: July 2, 2008 Proofs received from author(s): September 5, 2008 